\title{
POROSITY AND PORE SIZE DISTRIBUTION OF RECENT AND ANCIENT BURIED PHOEBE ZHENNAN WOOD DETERMINED BY MERCURY INTRUSION POROSIMETRY
}

\author{
Jialin Zhang, Hui Xiao, Yuzhu Chen, Jingiu Qi, Jiulong Xie \\ Xingyan Huang, Yongze Jiang \\ 1 Sichuan Agricultural University \\ CHINA \\ 2Key Laboratory of Wood Industry And Furniture Engineering \\ of Sichuan Provincial Colleges And Universities \\ China \\ (Received March 2020)
}

\begin{abstract}
The porosity and pore size distribution of recent and ancient buried Phoebe zhennan are studied in this paper by means of mercury intrusion porosimetry. The results show that the micropore and mesopore diameters of recent and buried wood are mainly distributed in range of $40.3 \mathrm{~nm}$ and $183.1 \mathrm{~nm}$ respectively, while the macropore in $45276.6 \mathrm{~nm}$ and $3503.9 \mathrm{~nm}$ separately. For both samples, the pores with diameters below $349.9 \mathrm{~nm}$ account for about $60 \%$ of the total intrusion volume, and contribute more than $98 \%$ of the surface area. The cumulative pore area of recent wood is slightly greater and the pore diameter ranges from $50.3 \mathrm{~nm}$ to $349.9 \mathrm{~nm}$. While the cumulative pore area of buried wood is significantly larger than and the pore diameter ranges until $50.3 \mathrm{~nm}$. These results can provide information for further investigations on the sorption behaviour and the liquid permeability of ancient buried wood.
\end{abstract}

KEYWORDS: Porosity, pore structure, Phoebe zhennan, ancient buried wood, mercury intrusion porosimetry.

\section{INTRODUCTION}

Buried wood refers to dead wood that is more than $50 \%$ buried by soil, garbage or ground vegetation through natural disasters such as landslides and river deposits or through excessive growth of ground vegetation (Jianyi et al. 2019, Moroni et al. 2015). The buried wood often persists many centuries (Boutelje and Bravery1968, Kim 1987, 1990) or even thousands of years (Hedges et al. 1985, Hoffmann et al. 1986, Liyama et al. 1988, Meyers et al. 1980). 
The process of wood burial appears to occur mainly through two mechanisms (Moroni 2015), rapid burial through catastrophic events such as landslides and fluvial deposition (Eden 1967) or gradual burial of downed deadwood through litter deposition and overgrowth by ground vegetation (Dynesius et al. 2010, Hagemann et al. 2010a, Moroni et al. 2010). Buried wood has different physical and chemical property from that of recently cut wood. The effect of time on the buried wood caused hemicelluloses degradation and a decrease in the crystallinity index and the crystallite length, resulting in an increase in the proportion of amorphous zones (Esteban et al. 2006). Because of this, the equilibrium moisture contents of the buried wood are higher than of the recent wood, both in adsorption and desorption (Esteban et al. 2008). In terms of the thermodynamic properties, the heat involved is greater in the buried wood than in the recent wood (Esteban et al. 2009).

Buried Phoebe zhennan (family: Lauraceae, category: Phoebe) wood is precious for its beautiful color and pattern, light fragrance, and is widely used in costly furniture manufacturing, handicraft carving and other fields. However, the ancient buried P. zhennan wood is hard to dry and easy to crack, which affects its processing and utilization. The deformation and drying characteristics of buried wood are related to its internal structural characteristics, especially the porosity and pore size distribution. At present, the researches on pore size distribution of wood and wood-based products by mercury intrusion porosimetry are studied (Zauer et al. 2014, Pfriem et al. 2009, Plötze and Niemz 2011, Gigac et al. 2017). But the study on the pore characteristics of ancient buried wood is rarely reported. The aim of this research is to study porosity and pore size distribution of recent and ancient buried $P$. zhennan, which can provide useful information, particularly on the liquid permeability, and supply technological characteristics in its industrial processing.

\section{MATERIAL AND METHODS}

Recent and ancient buried $P$. zhennan were both provided by a wood company located in Chengdu, Sichuan Province, China. The samples were obtained from an 80-year old $P$. zhennan tree that had been buried for approximately 1500 years, dating by means of conventional radiocarbon, Carbon-14 (14C), radiocarbon dating. Recent samples were obtained from an 86 -year old living tree. Both wood samples were placed in room temperature about $20^{\circ} \mathrm{C}$ conditions for air drying.

\section{Mercury intrusion porosimetry}

Porosity and pore size distribution of wood were tested by mercury injection apparatus (AutoPore IV 9500). The samples, with dimensions of $20 \times 10 \times 10 \mathrm{~mm}$ (longitudinal $\times$ tangential $\times$ radial), were cut by scroll saw from both woods.

Samples were immersed in non-wetting mercury, and measurements were then conducted by two processes of low and high pressure to increase the pressure steadily from 0 to $400 \mathrm{MPa}$. Mercury progressively intruded into smaller voids under the increased pressure. The pore volume could then be derived from the quantity of the intruded mercury. The pore size distribution can be determined according to Eq. 1 (Washburn 1921):

$$
d=-\frac{4 \gamma \cos \theta}{p}
$$

where: $d$ - pore diameter, $p$ - pressure, $\gamma$ - surface tension of mercury $(0.48 \mathrm{~N} . \mathrm{m}-1), \theta$ - wetting angle of mercury $\left(141^{\circ}\right)$ (Junghans et al. 2005). 


\section{RESULTS AND DISCUSSION}

The results of the mercury intrusion porosimetry measurements for recent and ancient buried P. zhennan samples are showed in Tab. 1.

Tab. 1: Mercury intrusion porosimetry test results of recent and ancient buried P. zhennan samples.

\begin{tabular}{|c|c|c|c|c|c|c|c|}
\hline Phoebe zhennan & \begin{tabular}{|c|} 
Total \\
intrusion \\
volume \\
$\left(\mathrm{mL} \cdot \mathrm{g}^{-1}\right)$
\end{tabular} & $\begin{array}{c}\text { Total } \\
\text { pore area } \\
\left(\mathrm{m}^{2} \cdot \mathrm{g}^{-1}\right)\end{array}$ & $\begin{array}{c}\text { Median } \\
\text { pore } \\
\text { diameter } \\
\text { (volume) } \\
(\mathrm{nm})\end{array}$ & $\begin{array}{c}\text { Median } \\
\text { pore } \\
\text { diameter } \\
(\text { area }) \\
(\mathrm{nm})\end{array}$ & $\begin{array}{c}\text { Average } \\
\text { pore } \\
\text { diameter } \\
(4 \mathrm{~V} / \mathrm{A}) \\
(\mathrm{nm}) \\
\end{array}$ & $\begin{array}{c}\text { Bulk } \\
\text { density at } \\
0.43 \text { psia } \\
(\text { g.cm } \\
\text { (g) }\end{array}$ & $\begin{array}{c}\text { Porosity } \\
(\%)\end{array}$ \\
\hline Ancient buried $P$ zhennan & 1.0909 & 65.44 & 113.7 & 34.7 & 66.7 & 0.521 & 56.812 \\
\hline Recent $P$ zhennan & 0.9678 & 25.95 & 255.2 & 55.2 & 149.2 & 0.577 & 55.841 \\
\hline
\end{tabular}

The bulk density (at 0.43 psia) of the buried wood is lower than that of the recent, which may be due to the degradation of cellulose and hemicellulose, so the porosity and total intrusion volume of buried wood are larger (Schniewind 1990). However, the median pore diameter (volume), median pore diameter (area), average pore diameter (4 V/A) of the buried wood are significant lower, indicating that most of the pore in the buried wood is smaller, which caused the total pore area of buried wood is more than 2.5 times larger than that of the recent wood.

Log differential intrusion versus pore diameter of recent and ancient buried $P$. zhennan are showed in Fig. 1. According to the pore size distribution, four pore size classes could be distinguished: macropores $(58 \mu \mathrm{m}-0.5 \mu \mathrm{m})$, mesopores $(500 \mathrm{~nm}-80 \mathrm{~nm}$ ), and micropores $(80 \mathrm{~nm}-1.8 \mathrm{~nm})$ (Plötze and Niemz 2011). There are two obvious peaks of recent P. zhennan, and the corresponding pore diameter of the two peaks are $45376.6 \mathrm{~nm}$ and $183.1 \mathrm{~nm}$. The pore structure of vary structural in hardwoods are showed in Tab. 2 (Butterfield 2006, Stamm 1972, Stamm 1967). It can be seen from the data in the Tab. 2, the pore with diameter of $45376.6 \mathrm{~nm}$ is mainly from vessels, while the pore with diameter of $183.1 \mathrm{~nm}$ are mainly from pit membranes of bordered pits. Compared with recent $P$. zhennan, the peak of ancient buried $P$. zhennan moves in the direction of small pore diameter and the corresponding pore diameter of vessels are $3503.9 \mathrm{~nm}$ and $7244.9 \mathrm{~nm}$, which due to the cell wall of buried wood were obviously compressed and more natural mineral deposits were deposited inside the vessels cavities of the buried wood (Jianyi et al. 2019). The pore diameter of ancient buried $P$. zhennan microcapillary (vessels, cavities of fibers, pit chamber apertures, pit apertures) are smaller than that of the recent $P$. zhennan, which reduces the gas and liquid permeability of the ancient buried $P$. zhennan, and results in water movement, adhesive penetration in ancient buried $P$. zhennan wood difficult. The corresponding pore diameter of pit membranes is $40.3 \mathrm{~nm}$, which due to pit membranes were blocked by natural mineral deposits adhered in cell wall of the buried wood.

Tab. 2: Pore structure in hardwoods.

\begin{tabular}{llc}
\hline Structural elements & Diameter & Pore shape \\
\hline Vessels & $20 \sim 400 \mu \mathrm{m}$ & Tubular \\
Cavities of fibers & $10 \sim 15 \mu \mathrm{m}$ & Tubular \\
Pit chamber apertures of bordered pits & $4 \sim 30 \mu \mathrm{m}$ & Ink bottle-like \\
Pit apertures of bordered pits & $400 \mathrm{~nm} \sim 6 \mu \mathrm{m}$ & Tubular \\
Pit membranes of bordered pits & $10 \mathrm{~nm} \sim 8 \mu \mathrm{m}$ & Polygonous spaces \\
Cell wall (dried) & $2 \sim 100 \mathrm{~nm}$ & Slite-like, cylindric, slite-like and cylindric \\
\hline
\end{tabular}




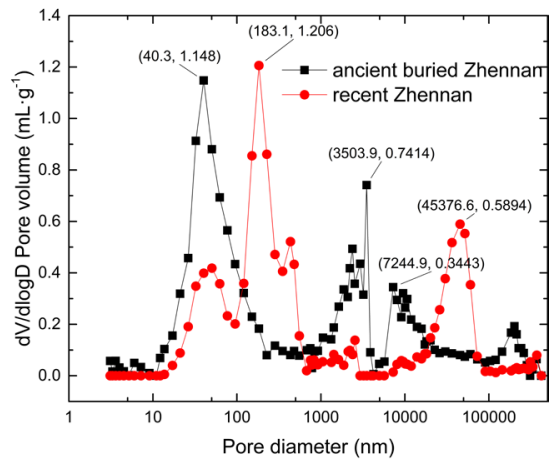

Fig. 1: Log differential intrusion versus pore diameter of recent and ancient buried P. zhennan.

Fig. 2 and Fig. 3 show the cumulative pore volume (CPV) and percentage of intrusion volume (PIV) versus pore diameter of recent and ancient buried P. zhennan. Fig. 2 indicates that the CPV and PIV of recent P. zhennan is greater than that of ancient buried P. zhennan in the pore diameter range from $3224.5 \mathrm{~nm}$ to $60385.8 \mathrm{~nm}$, which are mainly from vessels, cavities of fibers, pit chamber apertures, pit apertures from the data shown in Tab. 1, and it shows a similar phenomenon in Fig. 3 for the increase of percentage of intrusion volume.

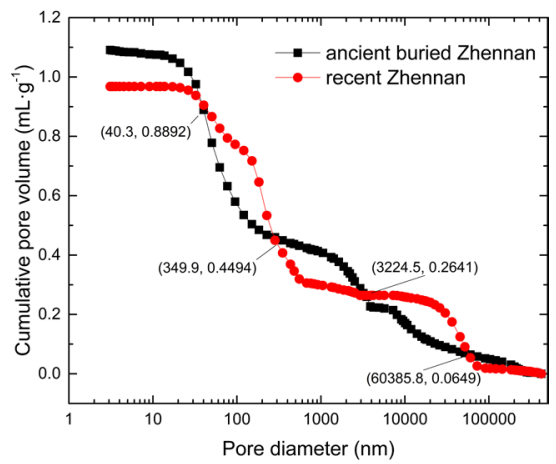

Fig. 2: Cumulative pore volume versus pore diameter of recent and ancient buried P. zhennan.

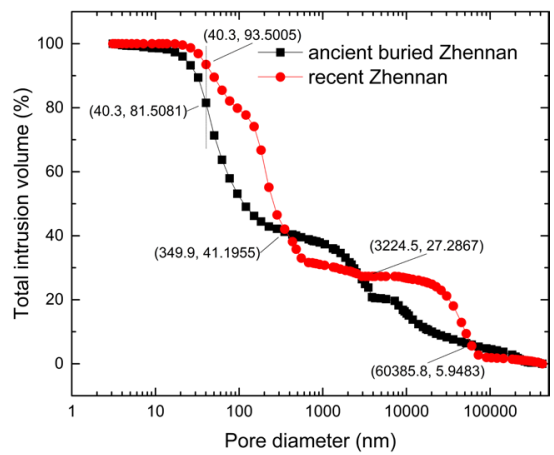

Fig. 3: Percentage of intrusion volume versus pore diameter of recent and ancient buried P. zhennan. 
The reason is the cell wall of buried wood were obviously compressed and more natural mineral deposits were deposited inside the vessels and fibers cavities of the buried wood, blocking the vessels, cavities of fibers, pit chamber apertures and pit apertures (Jianyi et al. 2019). The compression of cell wall and deposition of the natural mineral lead to the pore diameter range from $349.9 \mathrm{~nm}$ to $3224.5 \mathrm{~nm}$ of ancient buried $P$. zhennan is more than that of the recent $P$. zhennan, so the CPV and PIV of recent P. zhennan is less than that of ancient buried $P$. zhennan in the pore diameter range from $349.9 \mathrm{~nm}$ to $3224.5 \mathrm{~nm}$. The pore diameters range from $40.3 \mathrm{~nm}$ to $349.9 \mathrm{~nm}$ are mainly from pit membranes, the pit membranes of ancient buried $P$. zhennan were blocked by natural mineral deposits, so the CPV and PIV of ancient buried $P$. zhennan in this pore diameter range is less than that of recent $P$. zhennan. The pore diameters less than $40.3 \mathrm{~nm}$ are micropores in cell wall, the CPV and PIV of recent $P$. zhennan is more than that of ancient buried $P$. zhennan in this pore diameter range. This due to the microstructure of buried wood is destroyed after the transformation of the natural environment, causing a small amount of cellulose or hemicellulose to be degraded, which leads to the micropores in the cell wall of buried wood is more than that of the recent one (Jianyi et al. 2019).

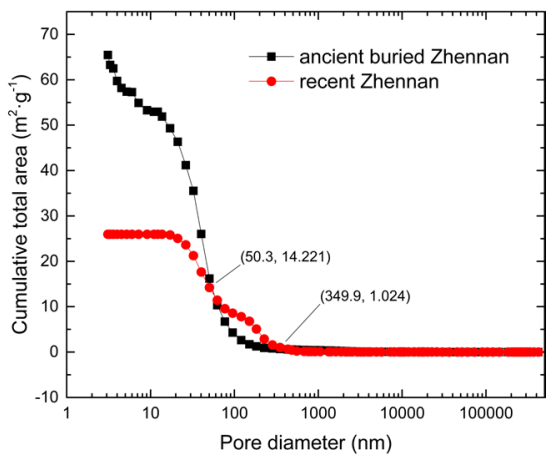

Fig. 4: Cumulative pore area versus pore diameter of recent and ancient buried P. zhennan.

Fig. 4 shows the cumulative pore area versus pore diameter of recent and ancient buried P. zhennan. It can be known from Fig. 3 and Fig. 4, for both recent ancient buried P. zhennan samples, the pores with diameters below $349.9 \mathrm{~nm}$ account for about $60 \%$ of the total intrusion volume, and contribute more than $98 \%$ of the surface area, while the pores with diameters above $349.9 \mathrm{~nm}$ account for about $40 \%$ of the total intrusion volume, and contribute less than $2 \%$ of the surface area. This can be explained by the surface area of micropores is much larger than that of macropores with the same volume. According to the log differential intrusion versus pore diameter of recent and ancient buried $P$. zhennan in Fig. 1, the micropore diameter of recent and ancient buried $P$. zhennan are distributed in $40.3 \mathrm{~nm}$ and $183.1 \mathrm{~nm}$ respectively, so the cumulative pore area of recent $P$. zhennan is slightly greater than that of ancient buried $P$. zhennan in the pore diameter range from $50.3 \mathrm{~nm}$ to $349.9 \mathrm{~nm}$, while the cumulative pore area of ancient buried $P$. zhennan is significantly larger than that of recent $P$. zhennan in the pore diameter range blew $50.3 \mathrm{~nm}$, which proved that the degradation of cellulose or hemicellulose leading to the micropores in the cell wall of buried wood is more than that of the recent one. 


\section{CONCLUSIONS}

The bulk density (at 0.43 psia) of the ancient buried Phoebe zhennan is slightly lower than that of the recent $P$. zhennan, while the porosity and total intrusion volume of ancient buried $P$. zhennan are a little larger. However, the median pore diameter (volume), median pore diameter (area), average pore diameter (4V/A) of the ancient buried $P$. zhennan are significantly lower than that of the recent $P$. zhennan, which caused the total pore area of ancient buried $P$. zhennan is more than 2.5 times than that of the recent $P$. zhennan. The micropore diameter of recent and ancient buried $P$. zhennan are main distributed in $40.3 \mathrm{~nm}$ and $183.1 \mathrm{~nm}$ respectively, while the macropore are main distributed in $45276.6 \mathrm{~nm}$ and $3503.9 \mathrm{~nm}$ separately. The pore diameter of ancient buried $P$. zhennan macrocapillary is smaller than the that of the recent $P$. zhennan, while pore diameter of ancient buried $P$. zhennan microcapillary is bigger than that of the recent $P$. $z$ zennan. For both recent and ancient buried $P$. zhennan samples, the pores with diameters below $349.9 \mathrm{~nm}$ account for about $60 \%$ of the total intrusion volume, and contribute more than $98 \%$ of the surface area. The cumulative pore area of recent $P$. zhennan is slightly greater than that of ancient buried $P$. zhennan in the pore diameter range from $50.3 \mathrm{~nm}$ to $349.9 \mathrm{~nm}$, while the cumulative pore area of ancient buried $P$. zhennan is significantly larger than that of recent $P$. zhennan in the pore diameter range blew $50.3 \mathrm{~nm}$.

\section{ACKNOWLEDGEMENTS}

The authors gratefully acknowledge the support of Education Fund of Sichuan Provincial Department (16ZB0049) and the Innovative experimental program for College Students of China (04054633).

\section{REFERENCES}

1. Boutelje, J.B., Bravery A.F., 1968: Observations on the bacterial attack of piles supporting a Stockholm building. Journal of the Institute of Wood Science 20: 47-57.

2. Butterfield, B., 2006: The structure of wood: form and function. Pp 1-22, Primary wood processing, Springer, Dordrecht, Pp.1-22.

3. Dynesius, M., Gibb, H., Hjältén, J., 2010: Surface covering of downed logs: drivers of a neglected process in dead wood ecology. Plos One 5(10): e13237.

4. Eden, W.J., 1967: Buried soil profile under apron of an earth flow. Geological Society of America Bulletin 78(9): 1183.

5. Esteban, L.G., Fernandez, F.G., Guindeo, C.A., De Palacios, P., Gril, J., 2006: Comparison of the hygroscopic behaviour of 205-year-old and recently cut juvenile wood from Pinus sylvestris L. Annals of Forest Science 63(3): 309-317.

6. Esteban, L.G., De Palacios, P., Fernandez, F.G., Guindeo, C.A., Cano, N.N., 2008: Sorption and thermodynamic properties of old and new Pinus sylvestris wood. Wood and Fiber Science 40(1): 111-121.

7. Esteban, L.G., De Palacios, P., Fernandez, F.G., Martín, J.A., Génova, M., Fernández Golfín, J.I., 2009: Sorption and thermodynamic properties of buried juvenile Pinus sylvestris L. wood aged 1,170 \pm 40 BP. Wood Science and Technology 43(7-8): 679-690.

8. Gigac, J., Stankovska, M., Fiserova, M., 2017: Comparison of capillary flow porosimetry and mercury intrusion porosimetry in determination pore size distribution of papers. Wood Research 62(4): 587-596. 
9. Hagemann, U., Moroni, M.T., Gleißner, J., Makeschin, F., 2010: Accumulation and preservation of dead wood upon burial by bryophytes. Ecosystems 13(4): 600-611.

10. Hedges, J.I., Cowie, G.L., Ertel, J.R., Barbour, J.R., Hatcher, P.G., 1985: Degradation of carbohydrates and lignins in buried woods. Geochimica et Cosmochimica Acta 49(3): 701-711.

11. Hoffmann, P., Peek, R.D., Puls, J., Schwab, E., 1986: Das Holz der Archäologen. Holz Als Roh- Und Werkstoff 44(7): 241-247.

12. Jianyi, J., Zhenzhong, G., Xianfeng, H., Yuanhua, S., Shuqi, C., Jin, S., 2019: Study on thermogravimetric, flammability properties and micromorphology of buried wood. Materials Research Express 6(10): 105106.

13. Junghans, K., Niemz, P., Bächle, F., 2005: Untersuchungen zum Einfluss der thermischen Vergütung auf die Porosität von Fichtenholz. Holz als Roh- und Werkstoff (63): 243-244.

14. Kim, Y.S., 1990: Chemical characteristics of water-logged archaeological wood. Holzforschung 44(3): 169-172.

15. Liyama, K., Kasuya, N., Tuyet, L.T.B., Nakano, J., Sakaguchi, H., 1988: Chemical Characterization of ancient buried wood. Holzforschung 42(1): 5-10.

16. Meyers, P.A., Leenheer, M.J., Erstfeld, K.M., Bourbonniere, R.A., 1980: Changes in spruce composition following burial in lake sediments for 10,000 yr. Nature 287(5782), Pp 534-536.

17. Moroni, M.T., Morris, D.M., Shaw, C., Stokland, J.N., Harmon, M.E., Fenton, N.J., Merganičová, K., Merganič, J., Okabe, K., Hagemann, U., 2015: Buried wood: A common yet poorly documented form of deadwood. Ecosystems 18(4): 605-628.

18. Moroni, M.T., Hagemann, U., Beilman, D.W., 2010: Dead wood is buried and preserved in a Labrador boreal forest. Ecosystems 13(3): 452-458.

19. Pfriem, A., Zauer, M., Wagenführ, A., 2009: Alteration of the pore structure of spruce (Picea abies (L.) Karst.) and maple (Acer pseudoplatanus L.) due to thermal treatment as determined by helium pycnometry and mercury intrusion porosimetry. Holzforschung 63(1): 94-98.

20. Plötze, M., Niemz, P., 2011: Porosity and pore size distribution of different wood types as determined by mercury intrusion porosimetry. European Journal of Wood and Wood Produce (69): 649-657.

21. Schniewind A.P., 1990: Physical and mechanical properties of archaeological wood. In: Rowell, R.M., Barbour, R.J. (eds): Archaeological wood: properties, chemistry and preservation, advances in chemistry series 225. Pp 87-109, American Chemical Society, Washington.

22. Stamm, A.J., 1972: Maximum effective vessel diameters of hardwoods. Wood Science and Technology 6(4): 263-271.

23. Stamm, A.J., 1967: Movement of fluids in wood. Part I: Flow of fluids in wood. Wood Science and Technology 1(2): 122-141.

24. Washburn, E.W., 1921: Note on a method of determining the distribution of pore sizes in a porous material. Proceedings of the National Academy of Sciences of the United States of America 7(4): 115-116.

25. Xie, J.L., Qi, J.Q. Huang, X.Y., Zhou, N., Hu, Y., 2015: Comparative analysis of modern and ancient buried Phoebe zhennan wood: surface color, chemical components, infrared spectroscopy, and essential oil composition. Journal of Forestry Research 26(2): 501-507.

26. Zauer, M., Hempel, S., Pfriem, A., Mechtcherine, V., Wagenführ, A., 2014: Investigations of the pore-size distribution of wood in the dry and wet state by means of mercury intrusion porosimetry. Wood Science and Technology 48(6): 1229-1240. 
Jialin Zhang, Hui Xiao*, Yuzhu Chen, Jingiu Qi, Jiulong Xie, Xingyan Huang, Yongze Jiang

${ }^{1}$ Sichuan Agricultural University

COLlege of Forestry

${ }^{2}$ Key Laboratory of Wood Industry And Furniture Engineering

of Sichuan Provincial Collegges And Universities

No.2i i, Huiming Road, Wenjiang District

Chengdu City, Sichuan Province, 6i irizo

China

*Corresponding author: shawwe@126.com 